\title{
Road Policing as a State Tool: Learning from a Socio-historical Analysis of the California Highway Patrol
}

\section{Fabrice Hamelin \& Vincent Spenlehauer}

The vast majority of Anglo-American police and policing social studies illustrate, both theoretically and empirically, an a-statist, localist and, to a lesser extent, privatist organization. This article reconsiders this common perspective by exploring the sociohistorical monographs of the California Highway Patrol. This inquiry reveals how a state can utilize a new and marginal policing objective-road risk and criminality - to develop a powerful and relatively autonomous police organization, which, despite its name, exists more as a police on the road than a police of the road, and plays a vital role in the Californian police system. Surprisingly, the California Highway Patrol embodies the model of a state institution much more common in "Older Europe" than in America.

Keywords: Policing; State; Road policing; Highway patrol; California; Institution; Profession

\section{Introduction}

In American academia, despite a steady flow of research substantiating meaning and substance to the state variable, the vast majority of police and policing studies illustrate, both theoretically and empirically, an a-statist, localist and, to a lesser extent, privatist organization. Yet, as presented by H. Kenneth Bechtel (1995), the state police model is no minor one in the United States as every state has its own. Overall these state police agencies employ more than 50,000 uniformed agents, with their operational costs representing close to 10 per cent of all American local and state police agency budgets.

\footnotetext{
Fabrice Hamelin and Vincent Spenlehauer are both at the Institut National de Recherche sur les Transports et leur Sécurité in Arcueil, France. Correspondence to: Fabrice Hamelin, Institut National de Recherche sur les Transports et leur Sécurité, Unité de recherche GARIG (Groupe d'Analyse du Risque routier et de sa Gouvernance), 23, rue Alfred Nobel, F-77420, Champ-sur-Marne, France. E-mail: fabrice.hamelin@inrets.fr
} 
Founded in 1929, the California Highway Patrol (CHP) is one of the 30 out of 39 state police agencies created between 1929 and 1941 as a road traffic police force (Bechtel, 1995: 44). The CHP's primary mission is to regulate traffic and roads hazards in California. However, seven decades after its creation, the CHP can be analyzed in paradoxical terms considering and yet beyond this primary mission. Many diverse features of the CHP make it a very unique component of the Californian police system at large. In effect, because of its official specialization in road matters, the CHP is the only state police organization of California, which has a total of 89 county or municipal police agencies. The CHP administration is a very bureaucratic and apolitical organization. For example, for more than thirty years, the post of CHP Commissioner was removed from the typical "spoil system" of political appointments and filled through promotion from the ranks of the CHP corps of officers. ${ }^{1}$ These officers form a civilian police body, yet are viewed and trained like a "semi-military organization" (Foss, 1960: 5). Unlike most Californian police agencies, the CHP is quite imposing in many respects. It has a current budget that runs at around US $\$ 1$ billion. It employs more than 10,000 personnel, of which 70 per cent are sworn officers. Only the Los Angeles Police Department and the Los Angeles County Sheriff Agency, each with more than 10,000 sworn personnel, are larger than the $\mathrm{CHP}^{2}$ Today, the 7,000 California Highway Patrol officers represent 12.5 per cent of California's police personnel.

Despite its unique characteristics, the CHP is very well integrated within the Californian police system and policing community. For instance, the CHP frequently sign (and renew) agreements with most of the Californian municipal police agencies in order to insure a reasonable degree of road policing uniformity on state territory and the maintenance of its original rural detachments. ${ }^{3}$ Nevertheless, the most important indication of its constructive involvement with local municipalities stems from the fact that, in functional terms, the CHP resembles more of a "general police on the road" than a (specialized) road traffic police. ${ }^{4}$ The content of the training received by the cadets at the CHP Academy and the significant number of retired CHP officers working for county police departments as a second career attest to the functional "generalism" of the CHP.

How the CHP is organized and outfitted must also be considered. For example, the "Los Angeles Riots" of 1992 demonstrated how well-prepared, organized and technologically equipped CHP police officers were in matters of crowd control, street control and coordination with other police organizations during a significant crisis situation. ${ }^{5}$ On a much more regular basis, these state civil servants participate in criminal investigations - notably those involving the use of road and vehicles (i.e., drug trafficking). Since 9/11, their recognized mastery and knowledge of what is happening on the Californian road network have enabled the CHP to collect large federal technological grants to carry out surveillance and intelligence duties and reinforce their already enviable means of action in this domain. The CHP is, without a doubt, one of the most powerful islands of the Californian police archipelago. ${ }^{6}$ 
How and why did such a police organization grow so successful in most measures clearly apart from the American police mainstream (urban, municipal, criminal, etc.) yet well inserted within the Californian police system? What made this sort of organization so attractive to successive Californian state governments? What roles were assigned to it and how did it develop? A socio-historical monograph of the CHP provides answers to these questions. It also provides support to Bechtel's idea that any understanding of the governance of the multitude of police agencies in the United States requires that the state police agencies be taken into account.

Our thesis is that the highway patrols can be seen as public organizations that have enabled certain American states to develop state supervision and oversight - with varying degrees of success-over typical police organizations deeply seated in localism. The founding of the CHP paralleled the expansion of road traffic and its resultant dangers in California. More importantly, the CHP enabled Californian state authorities the necessary law enforcement body to handle the many issues that developed with the perceived inadequacy of local police forces in this field that were so markedly lacking in the tense social context of the Depression. The CHP provided a dynamic solution in resolving the many problems within the local police forces at the time (e.g., corruption, excessive politicization and difficulty in maintaining order) by creating a state police body officially dispatched to deal with the emergence of specific safety and crime problems linked to the expansion of road traffic. We find here a good illustration of the reversal of the problem-solution sequence that characterizes the "garbage can model" (Cohen et al., 1972). As a result, the CHP became as much a police force on as of the road (Carnis et al., 2006).

Our study does not consider the CHP of today. Instead, it concentrates on the period of its foundation, between 1915 and 1953. We first show that the establishment of the California Highway Patrol in 1929 did not simply occur along with the wave of creation of specialized road traffic police forces identified by Bechtel. One must also situate this development in the context of a broader movement of police modernization through the creation of state police agencies. This movement accelerated just after the First World War (Wilson 2000). Strongly connected with the "Progressive Movement" spirit, the reformers defended the need to professionalize law enforcement - a process including the training of officers, reliable administrative procedures and autonomy from political machines, corruption and corrupt local governments. ${ }^{7}$

Like most other state highway patrols, the CHP has been totally ignored by the social scientists, with the exception of some descriptive case studies by graduate students (Gammage, 1959; Foss, 1960). In addition to these dissertations, we have examined the development of the CHP during the first part of the twentieth century relying on administrative and professional literatures ${ }^{8}$ (secondary materials) available at the California State Library (Sacramento) and the California University Libraries at Berkeley and Los Angeles. We have also used primary source materials located at the California State Archives (Sacramento). In this respect, we have processed different articles about the CHP, focusing more particularly on administrative files including 
general correspondence, memos and reports. These records pertain to all aspects of CHP operations with particular attention to highway safety, equipment, personnel, fiscal affairs and services.

Two sub-periods can be identified in the period under study. The first, 1915-1929, relates to the processes by which, after the promulgation of the California Vehicle Code, the idea of the CHP was developed to create a state police agency to control and monitor the use of the state's roads. The study of this period shows how and why the state of California took traffic regulation out of the hands of the counties. The second sub-period, 1929-1953, is that of the institutional, organizational and professional construction of the CHP in the more or less permanent form we see today. During this period, the CHP gained its autonomy and took on a distinctively paramilitary character.

\section{How the State of California Took Traffic Regulation Out of the Hands of the Counties}

The first phase in the history of road policing in California led to the creation of the California Highway Patrol in 1929. This "prehistory" is dominated by controversy over local and state roles in traffic management. In a context of constitutional jurisprudence, this controversy gave rise from 1923 onwards to a process of statecounty contractualization. However, what was quickly revealed as an unstable compromise was abandoned within a few years, with the state taking over policing of the roads throughout California - with the notable exception of the larger urban areas. Thus in the specific field of traffic regulation, the state held sway in the relatively non-urban areas beyond the purview of municipal authorities.

\section{Traffic Regulation: A Local Affair}

Following the American police tradition (L'Heuillet, 2003), traffic policing in California was not initially a state affair; rather it began, as in most other American states, at a strictly local level. Municipality and county were two distinct political and administrative territories, with traffic control the concern of one or the other. However, the patrols that were the basis of the CHP were exclusively those of the counties and the "traffic" components of the municipal police forces played no part in the process described here. At the time, in fact, very few municipalities in California had a "traffic section". Moreover, the municipalities, especially Los Angeles and San Francisco, were endowed with far greater political power and far more powerful police forces than the counties, and so were less inclined to give up this form of social control and the income that went with it. ${ }^{9}$

The emergence of traffic policing in the Californian counties would also seem to confirm the classic thesis of priority for social control in America's states. In the American context, exponential growth of car use as a social activity gave rise to a need for control that was met by the creation of traffic police forces. However, the absence 
of public order enforcement bodies at both county and state level must be seen as a driving force behind the creation of the CHP during a period marked by the rise of trade unions and intensification of social conflict. This hypothesis - the increase in road traffic as both a good reason and a sound pretext for political innovationprovides an explanation for the determination, and even aggressiveness, brought by the state of California to taking over traffic supervision from the counties. Thus, even if facilitated and settled by the legal system, the controversy regarding which level of government should shoulder this responsibility has political, non-juridical foundations.

\section{The Respective Roles of Local Government, the State and National Authorities}

Socio-economic change in California in the early decades of the twentieth century caused upheavals that provide an initial explanation of why the authorities put road traffic regulation issues on their agendas. The primary factor was the spread of the automobile, notably in the form of the Model $\mathrm{T}$ Ford. The number of vehicles registered in California rose from 6,428 in 1905 to 122,444 in 1913, to 1,120,875 in 1923 and 2,026,868 in 1929 (Moynahan, 1937). For subsequent years, see Figure 1. Other relevant factors are a massive influx of immigrants and an increasingly dangerous situation on the roads.

The county Boards of Supervisors were the first bodies to come to grips with these issues. The proliferation of automobiles led local government to introduce a host of regulations, together with local police forces to enforce them (Vollmer, 1936; Carte \& Carte, 1975: 89). The prehistory of these police bodies is thus part of a classical traffic law enforcement pattern: the passing of legislation (county laws, but also the regulations brought together in the California Vehicle Act), the creation of enforcement structures (local in this case) and the application of legal sanctions in the case of violations. Until the 1920s, the "traffic employees" were entirely controlled and paid by the Boards; they were local public-sector agents whose field of activity

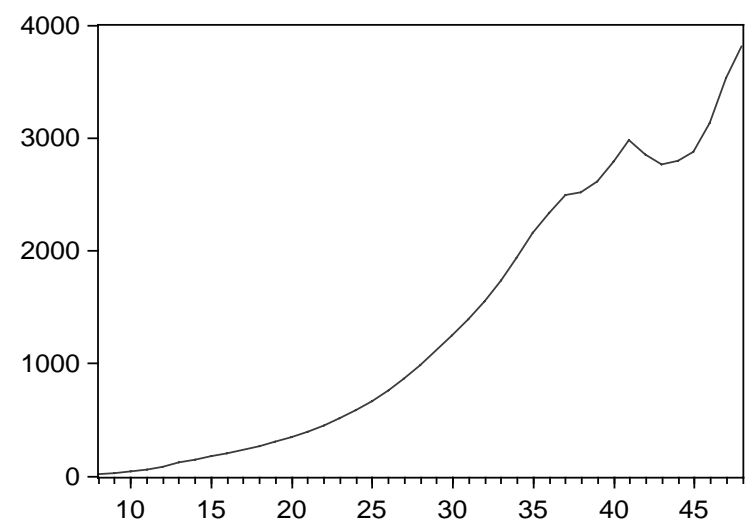

Figure 1 Cars registered in California (in thousands), 1900-1948. 
was defined by the county's public roads and their use, and whose task it was to ensure that things ran smoothly.

What we see, then, is a functional specialization of county agents in management of traffic-related problems. To cite one example, the functions entrusted to the "traffic employees" of San Mateo County in 1922 were to patrol the roads and highways of the county; to see that the relevant laws were enforced; to prevent trucks and other vehicles from using county roads when overloaded; to direct, manage and control the use of motor vehicles; to supervise the passage of other vehicles on county roads and streets; to foster free, rapid and continuous traffic flow and prevent congestion and accidents; to observe and check the state of county roads; to pursue via the courts any violations of laws and the Vehicle Code; and to draw up a monthly report for the Board including recommendations relating to regulation, management, protection and checking of county roads. ${ }^{10}$ This kind of functional specialization was not easily achieved. According to August Vollmer (1936), agents used to dealing with criminals had trouble adapting their repressive behaviour to the kinds of violations committed by road users; this explains why many counties did not incorporate traffic employees into their Sheriff's squad. ${ }^{11}$ This was not universally the case. According to Allen Z. Gammage (1959: 7), some or them wore both the patrolman's badge and that of deputy sheriff. Thus road safety agents remained on the fringe of the existing police system - a fact that throws light on the creation in 1920 of an association for the defence of the specific interests of these specialized agents: the California Association of Highway Patrolmen.

However, as indicated by the passing of the California Vehicle Act, the county authorities were not the only ones to take an interest in the consequences of the spread of the automobile. The beginnings of the relevant body of legislation in California dated from 1905, initially bearing on vehicle registrations. Passed in 1915, the California Vehicle Act was the first attempt to make the legislation at state level uniform: it created a Department of Motor Vehicles (DMV) responsible for issuing registration papers, driving licenses and license plates. Thus an embryonic state system came into existence. The Department superintendent had the right to hire peace officers, but the latter's function were limited solely to matters covered by the Vehicle Act. In practical terms, this form of state control developed slowly: Department policy focused first and foremost on prevention and education, on the one hand, and, on the other, coordination of measures taken by the counties, the cities and their police forces. Although well placed to note disparities in local practice, the inspectors were too few in number to do anything about them: the DMV had two inspectors in 1916 and 18 in 1923.

Traffic-related problems were also taking shape at national level. The National Safety Council began to publish road accident statistics in 1914, and in comparison with the rest of the United States, the data revealed a disastrous situation in California. There is other evidence of a budding national interest in matters of road safety and creation of the relevant tools. The first National Conference on Street and Highway Safety was held in 1924 under the chairmanship of the Secretary of State for 
Trade, although the 1920s saw only the very first measures towards facilitating coordination of responsibilities at national level. The creation of national tools was still in its infancy and the federal government was not yet involved. At national level, concern with coordination of public safety policies was primarily a professional affair, in line with the voluntary measures taken by police chief members of the International Association of Chiefs of Police (IACP).

\section{Social and Legal Controversy}

The massive expansion of car numbers after 1910 gave rise to a whole set of demands and strident social controversy: conflict between the horse and the car, challenges to the 1915 legislation by motorists who saw their freedom threatened, and calls for more and better roads (Teaford, 2002: 96ff). The largely sub-state-level handling of these issues gave rise to a lack of uniformity in the interpretation and enforcement of the law by the counties, which went hand-in-hand with the lack of a specific uniform for the highway police. The issue was considered sufficiently important for the California Highway Commission to declare itself in favour of the creation of a State Motor Police in 1922.

Immediately after the expression of this position, James B. Logan, a traffic officer in the employ of San Mateo County, took court action against the county treasurer for non-payment of his salary for the months of November and December 1922. The county's case was that the Board of Supervisors was not authorized to pay traffic officers out of general county funds. The matter went to the Supreme Court of California, which found that uniform traffic control was a state responsibility and that the counties had no power to employ traffic officers. Constitutionally speaking, said the Supreme Court, counties that did so were encroaching on state territory.

It clearly follows that as the duty of the petitioner (James B. Logan, traffic officer employed by the board of supervisors of San Mateo County) herein was to regulate traffic upon the public streets of the county of San Mateo, he was to that extent exercising a part of the sovereign power of the State and for that reason was a public officer as distinguished from a mere employee, such as a street-sweeper or laborers upon the highway.

It is clear, then, that the supervisors had no authority to pay or authorize the payment of the petitioner's salary...the petitioner was an officer and...the supervisors were without power to create such office. (Logan v. Shields, 190 Cal 661 1923)

A crucial factor in the implementation of traffic control in California, this decision emerged from a more or less classic employee-employer dispute. Nonetheless, the judges' decision opened a window of opportunity that California put to good use in modifying traffic control policy in the state. 


\section{Traffic Control: A State Matter?}

In the American socio-political context it can be readily understood that the policy adopted represented a compromise. It took the form of a contract between the state of California and its counties that created a reassuring image of partnership, but was quickly shown to be inappropriate. Nonetheless, the ins and outs of the solution led to a firming-up of the road patrol's police character.

\section{The Contract between the State and Local Government}

The legislative reaction to the Supreme Court decision was not slow in coming. The passage of the California Motor Vehicle Act on 30 May 1923 allowed the chief of the Division of Motor Vehicles to sign contracts with the county Boards of Supervisors and to employ in each county inspectors and "traffic officers" from a list drawn up by the county representatives. Section 159 of the Act set up within the state treasury a Motor Vehicle Fund whose resources, provided by the counties, would finance the division. Thus in 1923 the State of California signed contracts with 26 of its 58 counties, and 90 State Traffic Officers were recruited. Two years later, the number of contracting counties had risen to 36 , with 130 officers and 10 district inspectors. However, the legislation specified neither the pay scale nor the number of jobs, these being left to the discretion of the DMV director and, in practice, to the county councils. The result was a salary range varying from US\$150 to US\$250 a month (Gammage, 1959: 10). A further shortcoming of this "dual system of authority or control" was its instability. When the highway police refused to help the sheriff of Santa Barbara County to arrest local criminals, the Board terminated its contract with the state.

This dual system looked like an attempt at a compromise between the legal necessity to transfer authority to the state and the maintaining of local government rights. Yet in late 1923, the courts were called on to decide on the legality of the system, for the supervisor of state funds refused to pay out to officers any sum in excess of what the counties had provided. One of the officers (John Ryan, of the Sacramento squad) took the matter to law and a long battle began within the California courts. The system was declared unconstitutional (Ryan v. Riley, 65 Cal. App. Repts. 181-223), but this decision was quickly reversed by the Court of Appeal (07/01/1924), the Supreme Court having refused to become involved. Thus the problem of the disparities between counties in terms of interpretation and enforcement of the law remained pending.

The quality of police work continued to vary from one county to another and officers' prestige suffered from the favouritism certain lawbreakers enjoyed (Gammage, 1959: 11). In the second half of the 1920s, various bodies began pressing for the creation of a State Highway Patrol, among them the Automobile Club of Southern California, the California State Automobile Association, representing the rest of California, and the Commonwealth Club of California. ${ }^{12}$ At the same time, there was more diffuse social pressure for uniformity in terms of sanctions, so the issue of the legality of the system was overtaken by that of fair treatment for road users. 
The extent of the problems arising out of the 1923 compromise led to the formation of a Joint Committee of the Senate and Assembly in 1925, whose recommendations would be the basis of the 1929 reform. However, the first steps towards an appropriate structure were made possible by the window of opportunity opened by the decisions taken within California's legal and administrative-political system. An appreciation of the impact of this system is thus vital to any understanding of the initial establishment of the CHP. It is true that the institutional, sociological and economic contexts overlapped, but it is the representation of the respective roles of the state and local government that seems to play the leading role, together with the limited incorporation of highway police officers into the existing system of policing. Was highway policing thus entrusted to police officers? And did the contracting process lead to the setting up of a true police force?

\section{Highway Policing: Police or not Police?}

The jurisprudence of the 1920s and 1930s is unequivocal: legally speaking, patrolmen were officers with police powers and specific authority relating to police functions. The Court of Appeal finding (07/01/1924) in respect of Ryan v. Riley points out that, in accordance with the Section 30 of the Motor Vehicle Act, the inspectors and traffic officers are invested with the powers of "peace officers". And yet the powers of the county traffic officers, and then of the officers of the CHP were restricted to the stipulations of the Motor Vehicle Act and other legislation relating to the use of vehicles on public roads. They did not possess full police powers (section 29, California Vehicle Act 1931). Thus this policing measure has the singular feature of applying to two specific entities: motor vehicles and public highways in the counties. The officers could stop and check vehicles if they considered them unroadworthy or in violation of the Vehicle Act. They also had the right to check any motor vehicle on public parking lots or concessions.

There are three explanations for the legal restrictions on the powers of the officers of the California Highway Patrol. First, this specialization testified to the importance taken on by traffic control and vehicle checks. Second, in the American national view of things, the very principle of a single, centralized state police is seen as a threat to public liberties. It should be noted here that this restriction was not unique to California: between 1929 and 1941 only three of the states that introduced a state police gave the body full powers. Third, the highway police of the pre-1929 period was a local, easy-going affair whose potential for maintaining law and order could not be openly exploited. Dominant among the arguments put forward against the creation of state police forces was that of their use as anti-labour bodies (Bechtel, 1995: 17).

To take a more sociological point of view and invoke Weber's formulation, the task of the county patrols was "public control of private violence" (Monjardet, 1996: 19). Like the other police forces, they had to be capable of controlling all private initiatives exercised via the use of motor vehicles and/or on the public roads. This is why these police forces were initially subject to the specific authority of the counties. The 1920s, 
then, were marked by a mosaic of highway police agencies of different sizes, which had in common an emphasis on prevention of disorder and danger and on acceptance by the local community rather than on repression and constraint. The business of patrolling, like the way in which agents were recruited, gave concrete expression to this concern with minimizing the distance between the population and the highway police. These, then, were very much local or "community" police forces - always remembering that the community in the first instance was that of the county. Car use, however, produced a community less and less rooted in this restricted territory. The community ceased to be county-based, becoming instead a social one: the community of road and motor vehicle users. This shift highlighted the shortcomings and limitations of county control and justified both resort to the state and state takeover of highway police activities.

To sum up, the two separate processes - on the one hand, police professionalization, with anti-crime policing as the cardinal feature of professional identity and, on the other hand, political, social and demographic change in California - represented an instrumental problem of social control for the county authorities. The solution that emerged was the creation of a new type of police force distinct from the classical "crime-fighting" model. The surge of problems related to increasing car use in the 1920s provided the perfect excuse for the creation of new county police forces, but these did not long survive in their initial form. In less than ten years, the state of California succeeded in its bid to take over the small highway police forces. It was the state that made the CHP an order maintenance organization, representing the state in addition to being a community or local body.

\section{The CHP: Autonomy at State Expense}

As indicated by the conflicts that went to the courts, this major change cannot be explained solely in terms of factors external to the police system. Acceptance by the police group in question was vital. The change meant an unarguable increase in the group's resources and a boost to its members' status. The second phase in the creation of the CHP confirms this interpretation to the extent that it seems dominated by a thrust towards autonomy by the body founded in 1929 in relation first to local government and then to other state of California departments. Integration into the state apparatus went hand-in-hand with a process of administrative differentiation at state level. Professionalization of highway policing in California took on a distinctively paramilitary character.

\section{A State Police Agency}

This first structural measure led in 1929 to the creation of a Division of Highway Patrol (Senate Bill no. 869, 26 April 1929, passed 14 August 1929). The agents of the contract police forces became de jure members of the CHP, while agents from noncontract counties were given the right to join (Rubin, 1989: 10). The new legislation 
put an end to the contract policy and the existence of two kinds of highway police: contract and non-contract. The new division initially comprised of 280 uniformed men equipped with 80 cars and 225 motorcycles. Equipped and armed, this group was theoretically under the sole authority of the state government, but did not in fact become fully independent of the counties until 1937. Achieving autonomy in respect of the state administrative system proved to be even more difficult.

\section{Autonomization in Respect of the Counties}

The birth date of the CHP is considered to be 14 August 1929. This specialist police force was the outcome of the regrouping of the county motorcycle squads, whose agents then became state employees working six days a week for a monthly wage of US\$170 (California Vehicle Act 1929). Incorporation of local patrols into the CHP was gradual, however, and the counties with the largest populations were initially exempted from the system and maintained their existing patrols. Thus Los Angeles County was not incorporated until 1932. Allen Z. Gammage (1959: 13) puts this down to local pressure. In addition, the CHP chief was not allowed to assign an officer outside his county for more than a week without permission from the county. Recommendation of applicants by the counties remained current practice; this generated a split allegiance and hindered the development of the esprit de corps advocated by the first $\mathrm{CHP}$ chief, ${ }^{13}$ who fought to break the loyalty of highway patrolmen to the county authorities. Even today, although there is no reference to local authorities in the Vehicle Act, a CHP officer cannot be assigned for more than a week outside the county to which he has been appointed. And California is still not considered a uniform area in which highway patrolmen can feel free to apply standard behaviour anywhere and everywhere. What seems to have happened is that one particular initial measure became distorted: troop mobility and absence of local loyalty are major factors in effective law enforcement, but what looked like a means of anticipating and regulating the movements of this state police, while at the same time maintaining a certain loyalty to local authorities, is better analyzed today as a way of combining the resources of the two competing rationales. While a state base frees officers from political pressures, local connections enable the setting-up of an interaction and information network with the population and its representatives, and also with the other components of the local police system. ${ }^{14}$

In the course of the 1930s, a number of links with the counties were broken ("offlocalization"). In 1932, the first civil service examination was held for the entire state. However, only candidates declared eligible by local political authorities were allowed to take the exam. Thus the means of recruitment was largely founded on political patronage. In this kind of procedure, geographical representativeness and acceptance of local political autonomy took priority over any demand for competence; candidates were not even required to have any advance qualifications. Once again we find an illustration of the notion of the state apparatus as a direct reflection of civil society and not as a separate class. Thus access to this part of the labour market 
appeared relatively easy, or at least not independent of political influence. The work of closing the institution in on itself had hardly begun.

One of the main steps towards independence of local government came in 1937, when the counties lost their right to nominate CHP applicants (Rubin, 1989: 10). Seen in the context of the times, this decision is less surprising than it might appear. August Vollmer (1936), for example, was advocating consolidation and increased coordination of police forces at both state and federal level:

We would wipe out of existence all constables, sheriffs, village marshals, municipal police forces, the state motor vehicle police force, and a number of the other states forces that have police power, and substitute a carefully selected and well-trained body of men to do their work.

As Vollmer was well aware, this model of an all-purpose, centralized police force within the state under discussion was already functioning in many European countries. In Crime and the State Police, a book co-written with Alfred E. Parker in 1935, Vollmer speaks more specifically about the Spanish civil guard as "a national police body organized on military lines" (Douthit, 1992: 113).

The off-localization trend is also perceptible in the first issue of the monthly California Highway Patrolman, published in March 1937. In the 12 short paragraphs of the statement of intent, the word "California" is mentioned 13 times. This is a good illustration of one of the magazine's aims, which was increased effectiveness for the policy of the DMV (i.e., of the state body then in charge of this field). Another of the magazine's missions was to publish official information from state departments on road matters. More specifically, this information was intended to reduce the road toll in California: 3,132 in 1936, up 12 per cent from 1935 and the highest of any state in America. California then had some six million inhabitants. In terms of road accidents, 1936 and 1937 were catastrophic. Within this context, road accident data helped shift the highway policing frame of reference from the local towards the state.

Thus the organization founded in 1929 gradually came to depend solely on the state government, with responsibility for it transferring from the local/state to the state/national level. Can this shift be put down solely to external factors such as the legal constraints mentioned earlier, and the pressure exerted by the population and its representatives on state politicians? Or does it also reflect demands by members of the police profession generally? It must not be forgotten, for example, that the California Association of Highway Patrolmen predated the actual forming of the CHP and that its present-day representatives regard the Association as having played a key role in the creation of the Patrol. ${ }^{15}$ However, the integration of the CHP into the state apparatus could easily have happened without any mobilization of the agents directly concerned for the state was well aware of the both the usefulness and the exceptional level of competence of highway patrolmen. Furthermore, as illustrated by the overall law and order enforcement functions entrusted to the CHP during the 1930s, the government's political elite provided themselves with a paramilitary force charged with putting the law into effect. And finally, establishment of state control via 
integration was facilitated by the fact that patrolmen did not belong to the Sheriffs' squads, and by the shortcomings of the contract system.

\section{Integration of the CHP into the Administrative Structure of the State of California}

Between its founding and 1947 the CHP was integrated into the Motor Vehicles Division and then the Motor Vehicles Department. In this respect, the legislation of 1929 involved a process less of creation than of integration. This integration process was the source not only of demands for autonomy, but also of tensions whose effect was to reinforce the specific character and police identity of the CHP. In 1929, it was the recommendations of the Department of Finance that were followed, and not those regarding separation formulated by the parliamentary commission set up in 1925 . Since the passing of car registration legislation, the DMV was the body in charge of all matters relating to motor vehicles in California. In 1931 it comprised a Division of Registration in charge of registration of motor vehicles, a Division of Accounting in charge of managing revenue collected by the Department and a Division of Law Enforcement, which in fact corresponded to the California Highway Patrol. A fourth section, the Division of Drivers' Licenses, was added in 1933. Thus the DMV was in charge of all matters to do with motor vehicles in California. However, the entry of the CHP into this integrated administrative structure introduced dual control since the hierarchical authority of the Director of the DMV was faced with the professional authority of the Chief of the CHP. There was permanent tension between the two, but questions of personality aside, it must not be forgotten that the administrative agents of the DMV and the CHP represented quite different professions rooted in separate philosophies.

After the Second World War that the organization of the CHP was again debated. It would seem that the war had put a stop to any possibility of reform in this field: the legislation of 1944 and 1945 was intended to enhance the DMV Director's administrative control over the Highway Patrol. By contrast, in 1946, the International Association of Chiefs of Police recommended the separation of the two organizations on the grounds of increasing the CHP's efficiency as a police body: "Assignment of enforcement responsibility to a department primarily interested in non-police functions may result in the relegation of the enforcement function to a minor role not consistent with the public need."16 In 1947, the state governor called for a thorough reorganization and a host of different bills were proposed. Ultimately, on 1 October 1947, an autonomous highway police department (the Department of California Highway Patrol) was formed after a long debate between pro- and antisecessionists. Over and above the case made by the Kreml report, this reorganization can be explained by an accident-related and, to a lesser extent, political context ${ }^{17}$ that saw the CHP's law enforcement and traffic functions take priority over its function as a supplier of funds for the DMV. Coming after the slowdown due to the war and the return of the troops, the vehicle registration explosion and the marked rise in road fatalities were decisive factors in this regard (cf. Figures 1 and 2). 


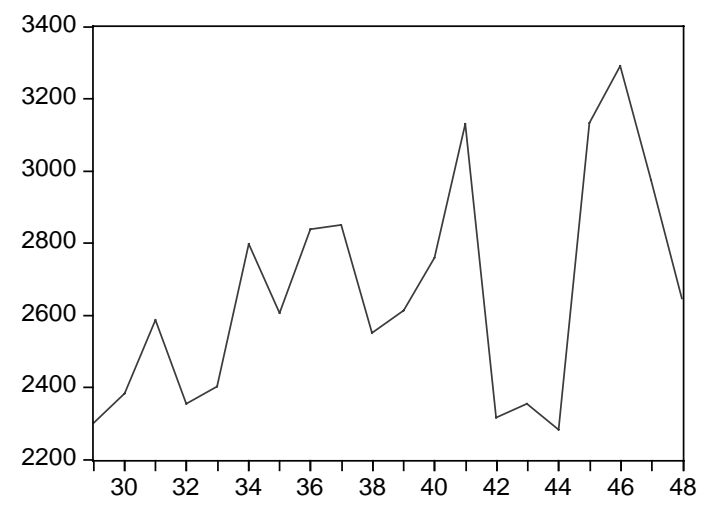

Figure 2 Number of road deaths in California, 1929-1948.

After relatively steady growth in the years 1929-1937, then stagnation due to the war, the number of CHP officers began rising in 1944 steeply enough to compensate to some extent for the wartime interruption. By 1947 the total was impressive: almost 1,000 agents (Figure 3). The most important features of this stage, which led to the creation of the Department of the CHP, were not only the Patrol's acquisition of institutional autonomy, but also the justification of that autonomy by the specific character of the work done by highway patrolmen. The CHP wasted no time in taking advantage of this greater autonomy and the substantial resources that became available to become not only a police "of" the road, but also a police "on" the road and a force for integration of the Californian police archipelago.

\section{A Police Force on, Rather than of the Road}

The CHP was an exception within the California police system and, more generally, in the United States. First, it was a state police force, and second, its primary mission was nominally that of the regulation of traffic and road hazards in California.

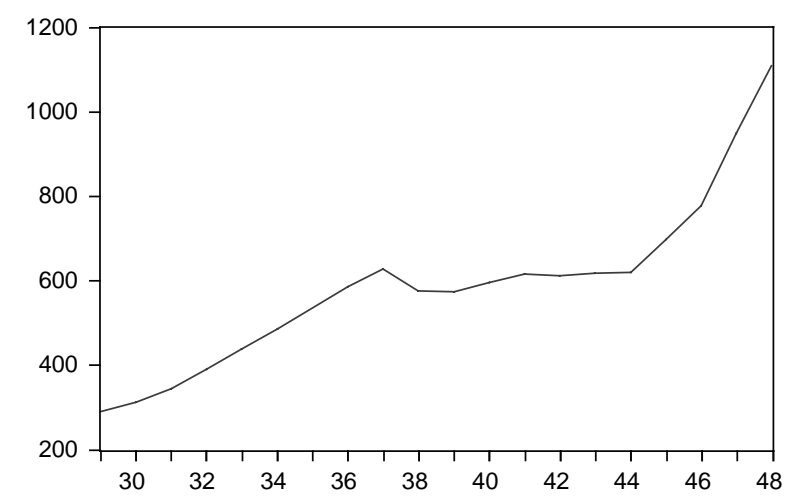

Figure 3 CHP officer numbers, 1929-1948. 
Paradoxically it was by accepting and cultivating this abnormal status that the CHP integrated and was integrated into its police context: the state of California maintained the CHP's appearances as a police force of the road, while rapidly transforming it into a police force on the road. It is not for nothing that the "P" in CHP stands for "Patrol" and not "Police". This leaves intact the founding myth of each American police force as rooted in a local community that it serves and protects. Moreover, the police functions entrusted to the CHP were exercised by agents whose professionalism was quite exceptional at the time: the CHP was structured as, and appeared to be, a "paramilitary" corps inspired by the European law enforcement model of the time.

\section{The CHP as a State Police}

As a group, the highway police may have taken shape in a non-state context, but there is no doubt that at the end of the process we are about to outline, it was controlled, financed, legitimized and shaped by and for the state of California. Its body of officers moved gradually towards the state-driven model of the "professional body" perhaps best exemplified by the French civil service's "corps" (Dubar \& Tripier, 1998: 33ff; Suleiman, 1978). The highway police was set moving by an occupational group specializing officially in enforcement of traffic legislation. As already indicated, this group sprang up independently of the state and management of its professional interests preceded by almost ten years of the birth of the actual police institution. This early organization in the defence of the group's corporate interests had to do with the agents' initial functional specialization and their distinctive identity as motorcyclists. A further factor was the dispute over control of the highway police between the state and counties and the shadow of uncertainty it threw over the emerging profession. It is interesting to note that in the course of the prehistory of California's highway police, county traffic officers supplied their own uniforms and used their own cars, paid their salaries with the fines they imposed, and had their gasoline and motorcycles provided, as a form of advertising, by local garages, car dealers and so on (Rubin, 1989: 9; Gammage, 1959: 7-9).

In the course of the 1920s, however, the legal cases brought by members of the highway patrols allowed the state to integrate, organize and shape this emerging profession. Once the counties had signed contracts with the state, and even more so when the patrolmen became state of California civil servants, the liberal model was no longer adequate to the development of the profession; in addition, legislative input began with the California Vehicle Act of 1925. Patrolling was the primary function of officers, whose role was essentially reactive, but inspection of school buses and bus drivers' licenses were added in 1933. In 1935, a stolen car bureau was created within the CHP. In addition, the Patrol was called on to intervene in many rural labour conflicts during the 1930s, sometimes with great violence-notably the largescale, bloody Corcoran Cotton Strike and Orange County Citrus Strike (Gammage, 1959: 17). They also intervened after the Long Beach earthquake in 1933 in an 
operation that highlighted the CHP's extreme mobility, as well as their general purpose police function.

In the tense social climate of the Depression, some of the CHP's missions were clearly those of a general police force. Under the control of the Executive of the state of California, the Patrol was used as a law enforcement body, and outside the periods of crisis its agents, uniformed and armed, played the "theatrical role" that characterized police forces - including local ones - on an everyday basis. ${ }^{18}$ This use of the CHP is readily understandable. The organization took shape in a context in which different social and political actors were agitating for the creation of a state police agency with broad police powers. ${ }^{19}$ The lines of argument used to back these proposals stressed the need for the state of California to provide itself with the means necessary to combat organized crime. And yet it should not be forgotten that the California of the time was solidly Republican (Starr, 1985: 275) and home to a powerful, growing conservatism that found particular expression in fighting socialism. None of the bills aimed at setting up a state law enforcement body were passed, but the CHP's role was extended in this direction.

The "policification" of the CHP can also be followed via the curriculum vitae of its first chiefs, who were policemen first and traffic specialists second. The first superintendent, Eugene W. Biscailuz, was previously deputy sheriff of Los Angeles County and his assistant Roy Youngblood deputy sheriff of San Joaquin County. Biscailuz was succeeded in 1931 (he then became Sheriff of Los Angeles County for almost thirty years) by R. Cato, chief detective of the LAPD. Cato bore the title of "Chief of the California Highway Patrol", with "Chief" being changed to "Commissioner" in 1947. The first real traffic policing expert (in Weber's sense) to run the CHP was Bernard R. Caldwell, appointed Commissioner in 1953. He had joined the LAPD as a patrolman in 1925, and in 1941, after a year's training at the Traffic Institute of Northwestern University, was named Deputy Chief of the LAPD's traffic bureau. He held this post until his appointment as CHP commissioner by Governor Earl Warren.

Thus the "policification" process outlined above cannot be seen merely as part of the trend towards standardization of the CHP in the light of the American police model. The professional identity of the highway patrolmen - quite distinct from that of the other peace officers - was made more structural by the fact of meeting a clear and legitimate social state need: traffic regulation for economic purposes, road accident prevention, the need for a highly mobile state police and so on. In other words, "policification" was much less visible in professional than in functional and institutional terms. Although a later development, the separation of the post of Commissioner from the spoil system points up in another way the closing-off of the CHP as a professional body. The ultimate step was taken in the 1980s with the choosing (since become standard practice) of the Commissioner from within the ranks of CHP officers. This closing-off process was also fostered by the Patrol's quasimilitary corporatism. 


\section{The Paramilitary Character of the CHP}

As early as 1929 the term "militarized police force" was an accurate description of the CHP, although its case-specific meaning has to be recognized and the model's underlying rationales understood. The latter have to do with socio-technologies of paramilitary or just plain military police ideas imported from Europe because they appeared to work well in handling the variety of particular problems with which the CHP had to cope. In the Patrol, general directives are issued as formal "orders". Insignia of rank are worn on uniforms. Officers were also sometimes referred to as "good soldiers", and physical fitness receive considerable emphasis (Foss, 1960: 5). Of course, these characteristics exist in many other law enforcement agencies. The urban polices created in the United States at the end of the ninetieth century resembled the military as well. They had a hierarchical military-like organization, were conceived to be active and not specifically responsive, and were put under the executive rather than judicial power. Those policemen wore uniforms with insignia of rank that made them visible and accessible to all (Monkkonen, 1996: 203-204). Moreover, early twentieth-century American advocates of state police forces took eighteenth- and nineteenth-century Irish and Canadian centralized paramilitary bodies as models (Bechtel, 1995: 26). However, the military character of the CHP displays the signs of a very specific period, between the First and Second World Wars. As mentioned above, August Vollmer makes reference to the Spanish Guardia Civil. In effect, at this time, the dominant model of a paramilitary force combines the hierarchical structure and the values of the army with law and order maintenance functions as exerted by urban police forces. $^{20}$

D. Monjardet (1992) prefers the term "disciplined professionalism". However, in the case in point, this expression is not totally satisfactory either for it does not take sufficient account of the potent values underlying the CHP: fraternity, esprit de $\operatorname{corps}^{21}$ and personal sacrifice, for example. To sum up, then, the CHP is a militarized police force in the sense that like career soldiers, California's highway policemen are chosen then "tailored" in an context that combines education and professional socialization; in the sense that like career soldiers they make up a hierarchical, highly integrated and massive body; in the sense that they are specially trained, equipped and armed for the tasks entrusted to them; and above all, in the sense that, like professional soldiers, they have been prepared, physically and mentally, for the worst. $^{22}$

However, institutional mimicry alone cannot explain the militarization of the CHP, and the model needs to be considered in terms of a rationale of institutional differentiation in relation to the social, administrative and political environment. One of the characteristics of the military institution is its self-containedness, notably its tendency to develop specific organic and ethical characteristics. For example, if the insistence on having roots in the local context remains, which is the case for the CHP, the dangers of favoritism or leniency also have to be anticipated. In this respect, potent professional ethics and self-regulation represent an undeniable asset. 
The modalities of recruitment and training of CHP agents were a vital part of this process. The 1929 legislation laid down clear rules for entry, requiring that all recruiting (other than incorporation) proceeds via examination and that a training school is established. Thus the history of the training of CHP officers is very largely coeval with that of its Academy, which in this early period was still chaotic (Gammage, 1959: 140). The first school was set up a year after the creation of the Highway Patrol in the ad hoc premises of the California State Fair Grounds in downtown Sacramento, where it remained until 1938. It then moved regularly until 1947, when the legislation creating the Department of the CHP stated, for the first time, that officers must undergo appropriate training.

The programme combined an initial period of schooling (theory and behavioural education) with further training throughout the officer's career. Use of firearms was part of the programme and included training with moving targets and self-defence (White, 1937). Teaching put considerable emphasis on the law (the California Vehicle Code, Penal Code, etc.) and on acquisition of technical knowledge appropriate to the profession of patrolman. The other component of the training provided was even more decisive in terms of group structuring: this was an ethical and behavioural education, which in many respects resembled military training: the definitions of discipline and obedience, for example, were the same as in the national military institutions (Gammage, 1959: 152ff). In addition to this formal, supervized training there was another more informal and implemented on an everyday basis via the example and the social control of the educators. It imbued students with the level of rigour deemed necessary, and with highly controlled behavioural responses, while activities requiring cohesiveness channeled them towards a sense of professional community.

The move to the present site on Meadow View Road, south of Sacramento, in 1953 was a vital step, ${ }^{23}$ allowing the education of trainees to take place in what as become a shrine to the Patrol's memory and history. The CHP Academy lent itself to the development of initiatory rites, the most edifying of which established veneration for those who had died on active service. This veneration is acted out through the meticulous cleaning, by each pupil, of the individual plaques bearing the names of officers "killed in the line of duty" and affixed to the monument in the school's central square. This "cult of the dead" extends to both officer victims of road accidents as well as gunshot wounds suggesting a combined police/paramilitary identity. The American context is especially important here. Given the ready availability of firearms, police work is more dangerous. ${ }^{24}$

Finally, the institutional design of the CHP meets the functions assigned to it, especially given that the administrative model aims to guarantee efficiency. As in the army, the specifically military character has to do, on the one hand, with ensuring the reliability of the police institution in carrying out its duties and making good use of the resources allotted to it: firearms and the law. It also has to do, on the other hand, with CHP officers' relationships with society and the political powers that be. The latter are only going to arm those they can trust to be loyal and not turn their arms 
against society. This is obviously a core issue in a country where the very idea of a state police is seen as a danger to individual and local liberty. It also offers an organizational and managerial response to the generalist trope of the CHP and, particularly, its intervention in the controlling of social conflicts in rural areas. Seen in this light, militarization seems to offer "solutions" to some of the specific characteristics of the CHP as an institution. Telecommunications advances now mean that the risk of errors stemming from officer autonomy in the field can be technologically managed, while in traditional terms, experience, coolheadedness and self-control limit this kind of risk. According to the same rationale, the group's esprit de corps and system of subordination represent protection against the "hierarchical inversion" some authors see as inherent in policing as a profession (Monjardet, 1996: 88f). In the final analysis, the importing of this organizational solution brings a response to the special features of the profession of policeman on the road.

\section{Conclusion}

The institutionalization of the CHP proceeds from what French socio-historians describe as a dual process of state control: "the penetration of the state into society" and the "administrative controlling" of social activities (Offerlé, 1997). With the CHP, the Californian government has de facto provided itself with a large and fairly classical state police force. The fact that in 1996 the California State Police, with its 400 agents, was purely and simply merged with the CHP illustrates that the state control examined in this article up until 1953 still exists today. As a result, in policing terms, the state of California resembles — surprisingly — what some authors describe as a "strong state" (Tilly, 1992).

However, our analysis also reveals the strangeness of this police force in relation to other concrete examples observable in the United States and elsewhere. It is a police force that can and regularly does play a part in law enforcement, yet this is not the main point of the demands made of it by government authorities at local, state and federal level. It is a police force that can and does perform criminal policing, but this activity is not a core part of the professional identity of CHP officers. It is a local peacekeeping force, but one that reacts largely to social demands regarding a specific form of criminality, delinquency and antisocial behaviour: that relating to car and road use. Established in the light of three archetypal criteria in the police social science field, these three characteristics underlie the CHP's oddness. These data might also explain why this police force, officially responsible to the Agency of Housing, Transportation and Business and not to the Californian Department of Justice, too often remains in the shadows.

The oddness of the CHP lies in its being the outcome of a meeting between two normally parallel and even incompatible processes: the shaping of a fairly classical bureaucratic, centralizing state (in this case at the instigation of the Progressive Movement) and a process of self-organization by civil society leading to the formation of a professional group. Thus in policing terms, from the 1920s onwards 
the State of California acted much more like a "reactive-hierarchical state" than a "reactive-coordinate" one (Freidson, 2001). Otherwise it would have let the pre-1923 situation continue, with the counties employing freelance "traffic employees" whose expenses and equipment were co-financed by private individuals and whose professionalization was a purely personal affair. It is quite remarkable today to see the administrative professionalism of the CHP feeding into, as well as channeling as expert adviser or supplier of expert personnel, private initiatives (business security) and community ventures (Neighborhood Watch) in terms not only of highway policing, but of policing in general.

On the other hand, the statist and policing institutionalization of the CHP has gone hand-in-hand up to the present with a growing autonomy on the part of the "institution-profession" (Abbott, 1988) within California's state apparatus. After a relatively short initial period marked by a triple dissociation-institutional, organizational and professional-from other (local) police forces in California, the CHP has constantly taken advantage of its autonomy to become a fully-fledged group actor on the Californian police scene. Its status as a state department has not taken the CHP off the counties territories, but rather set it free from the counties frontiers constraints. Gradually the California Highway Patrol has used part of the considerable material, technological and, above all, human resources (work capacity, skill, expertise) provided for its primary mission of regulating violence and danger on an inherently trans-jurisdictional road network, to deliberately offer aid and coordination to local Californian police forces: law enforcement, assistance in the event of natural disasters, surveillance of official buildings and major sporting events, information, participation in major criminal investigations (especially drugs and arms trafficking), neutralization and arrest of dangerous maniacs and so on. Last but not least, in addition to its crime-fighting activities and backup for local police forces, the CHP acts as a visible deterrent, helps road users in distress, lectures minor offenders, shows finely honed communication skills in its dealings with the citizenry and spends a great deal of time in schools. Thus it occupies, regulates and penetrates in no uncertain manner a physico-social territory: half the state of California road network and its users. The CHP has further improved its insertion into its social environment by setting up liaison committees with road user associations and civil rights defence groups, and by applying positive discrimination in its recruitment and training in the form, to cite one example, of eliminatory tests in Spanish at the end of the CHP Academy training programme.

One consequence, given the increasing importance of road use in social life in California together with the corporatism of the highway patrolmen achieved via a quasi-militarization of the CHP officer corps and their accumulated expertise, is the question of the extent of the control exerted by successive state governments on the $\mathrm{CHP}$ and of possible competition from other actors. It now seems reasonable to wonder if the CHP is not likely to become the integrating actor for public safety measures within California. Whatever the case, our study suggests that in the present epistemological context in which the governance/public action coupling is tending to 
replace the government/public policy one the state can retain a significant presence; and that some of its components are not short of inventiveness when it comes to preserving and enhancing their centrality in their own particular spheres.

\section{Notes}

[1] In 1972, Walter Pudinski, nominated by Governor Ronald Reagan, became the first CHP officer to lead CHP.

[2] In terms of size, the CHP occupies the fifth rank of police agencies in the United States (regardless of the federal level). In California, the fourth largest police force after the LAPD, LASCP and the CHP, is the San Diego Police Department which employs 4,000 agents (sworn and unsworn).

[3] As a result, the CHP directly controls half of the California's public road network (105,000 miles), but keeps the right to intervene on the other half if necessary. Although more than two-thirds of the network controlled by the CHP is located in rural areas, the majority of the CHP personnel work in urban areas where most of motor traffic takes place (especially on urban freeways that belong to the state and are exclusively patrolled by the CHP).

[4] At an early stage of the CHP history, its generalist trope has been diagnosed and even criticized (cf., e.g., Senate Finance Sub-Committee, Report on California Highway Patrol, 4 March 1953, California State Archives, 69-404). The absorption by the CHP of the 400 agents of the California State Police in 1995 constitutes another indication of the CHP generalist orientation.

[5] California Highway Patrol, Office of Research and Planning, 1992 Response to Civil Unrest Sparked by the Rodney King Incident Trial Verdicts, 1993, State California Library, H327 C59. It might be remarked that Rodney King was arrested by the LAPD on 3 March 1991 at the request of the CHP, which had initiating a pursuit of his vehicle on Interstate 210 until he left this highway to enter the LAPD jurisdiction. This fact constitutes another indication of the routine cooperation between the CHP and other Californian police agencies.

[6] The measurement of power is always delicate and subject to discussion. We based ours on the simple but very sound "NATO" analytical grid (Hood, 1983). "NATO" stands for: Nodality, Authority, Treasure, Organization.

[7] H. Kenneth Bechtel (1995) establishes a close link between the creation after the First World War of state police forces in the United States and the progressive movement reminiscence (see also Monkkonen, 2002 [1997]: 158-161). It must also be mentioned that in this period the main national figure of police professional reformism was August Vollmer. Chief of the police of the city of Berkeley between 1905 and 1932, he made California a laboratory of police innovation (Douthit, 1992 [1975]), partly with the help of his good friend Richardson, state governor between 1922 and 1926.

[8] E.g. : "A Chronological Development of the Problem of Traffic Control in the State of California and the Subsequent Development of the Department of CHP, 1911-1959", 1960, California State Library, Gvt, H325 H5l C3; "The California Highway Patrol: A Review of its Organization, Functions and Operations", Legislative Analyst of the Joint Legislative Budget Committee of California, 1960, California State Library, GPS, L425 H541; "70 years of the CHP", The California Highway Patrolman, special issue, August 1999.

[9] In fact, as far as our side-researches led us, it seems that the histories of traffic policing in municipalities and counties have taken two different paths. As early as the 1920s, the National Safety Council's urban elite networks encouraged American municipal polices to invest manpower and competence in traffic law enforcement. In the 1930s, following the excellent results of the Evanston's "traffic accident prevention bureau" set up by Franklin 


\section{F. Hamelin \& V. Spenlehauer}

Kreml, the National Safety Council (located in Chicago, Illinois) played a key role in the creation of the Northwestern University's Traffic Institute, which designed and implemented intensive training programmes mainly for municipal police officers aimed at creating and managing traffic bureaus in their organizations. In 1936, Franklin Kreml, who headed the Traffic Institute for more than twenty years, became also the chief of International Association of Chiefs of Police's traffic division. He represented and enacted a model of road policing, alternative to that of the CHP, mainly focused on urban areas and certainly more incorporated into the classic American urban police system.

[10] Section 3, Ordinance no. 320, passed 26 December 1922 by the San Mateo County Board of Supervisors.

[11] Unlike most aspects of road policing, the tensions between road policemen and road users have been well studied by academics: for England, see Emsley (1991); for France, see PérezDiaz (1998); for Australia and New Zealand, see Wilson \& Chappell (1971).

[12] "A Chronological Development of the Problem of Traffic Control in the State of California and the Subsequent Development of the Department of CHP, 1911-1959", pp. 3-4.

[13] E.R. Cato, Chief of the California Highway Patrol, Recommendations for the Future Improvement of the CHP, October 1934, p. 13.

[14] It is now explicit CHP policy to encourage captains to develop and maintain a relationship portfolio within their area. For a study of the importance of relationship portfolios in police work, see Thoenig (1994).

[15] Interview with three representatives of the CAHP (Sacramento, 5 August 2003).

[16] Franklin M. Kreml, Report on the California Highway Patrol to the Senate Interim Committee on Governmental Reorganization, 16 October 1946, p. 15 [California State Library, L500 I6 1946].

[17] In the investiture address following his re-election as Governor in January, Earl Warren made "civilizing" the state's roads a vital part of California's development: "Our streets and our roads have become places of frightful danger, and our economic development is being retarded ...".

[18] See the cover of the first issue of The California Highway Patrolman (Vol. 1, no. 1, March 1937). Symbolically it shows a review of the troops on the Bay Bridge linking San Francisco to Oakland, complete with revolvers and motorcycles. On the theatrical function, see Peter Manning (1991).

[19] Among them were the California Taxpayers' Association and the District Attorney of Alameda County, Earl Warren, who would become General Attorney in 1939, before being elected Governor in 1943 (and re-elected in 1947 and 1951). As Governor he demanded the total reorganization of the CHP that led to the establishment of an autonomous department in 1947.

[20] Of course, this type of paramilitary force differs very much from the "police paramilitary units" (PPUs) or "Special Weapons and Tactics teams" (SWAT), which developed in the large American municipal polices (i.e., the LAPD since the early 1970s) (Wilson, 2000; Kraska, 2001).

[21] The cardinal values of CHP officers are embodied in the acronym "CHP PRIDE": Courage, Honesty, Professionalism - Principles, Respect, Integrity, Dedication, Esprit de Corps.

[22] Regarding the features and causes of the "semi-military" organization of the CHP after 1947, see Philip O. Foss (1960: 5-6), who emphasizes in particular the emergency situations in which CHP officers frequently find themselves involved.

[23] On the decisive influence of a "long period of training in a school context" on the development and maintenance of a "specifically military character", see Hamelin (2003).

[24] For an illustration, see Sid Ziff, "Murderous Traffic Thug Shoots Patrol Officer: Perils of Highway Patrolman Again Proved", Los Angeles Herald Express, 22 September 1937 (reprinted in the California Highway Patrolman). 


\section{References}

Abbott, A. (1988), The System of Professions: An Essay on the Division of Expert Labor, University of Chicago Press, Chicago, IL.

Bechtel, H.K. (1995), State Police in the United States: A Socio-historical Analysis, Greenwood Press, Westport, CT/London.

Carnis, L., Hamelin, F. \& Spenlehauer V. (2006), Les polices de la route. Une approche comparée. Etats-Unis, Nouvelle Galles du Sud et Nouvelle-Zélande, Les rapports de I'NRETs no. 269, Paris.

Carte, G. \& Carte, E. (1975), Police Reform in the United States: The Era of August Vollmer, 19051932, University of California Press, Berkeley, CA.

Cohen, M.D., March, J.G. \& Olsen, J.P. (1972), "A garbage can model of organizational choice”, Administrative Science Quarterly, Vol. 17, no. 1, pp. 1-25.

Douthit, N. (1992 [1975]), August Vollmer, Berkeley's first Chief of Police, and the emergence of police professionalism, in: Monkkonen, E. (ed.) Policing and Crime Control, Saur, Munich.

Dubar, C. \& Tripier, P. (1998), Sociologie des professions, Armand Colin, Paris.

Emsley, C. (1991), "Mother, what did policemen do when there weren't any motors?" The law and the regulation of motor traffic in England, 1900-1939, in: Robert, P. (ed.) La Création de la Loi et ses Acteurs: l'exemple du droit pénal, Onati Proceedings, Onati.

Foss, P.O. (1960), Reorganization and Reassignment in the California Highway Patrol, University of Alabama Press, Tuscaloosa, AL.

Freidson, E. (2001), Professionalism: The Third Logic, Polity Press, Cambridge.

Gammage, A. (1959), The California Highway Patrol: A Study in Administration, doctoral dissertation, University of Texas-Austin.

Hamelin, F. (2003), "Le combattant et le technocrate: la formation des officiers à l'aune du modèle des élites civiles", Revue française de science politique, Vol. 53, no. 3, pp. 435-464.

Hood, C.C. (1983), The Tools of Government, Chatham House, Chatham.

Kraska, P.B. (ed.) (2001), Militarizing the American Criminal Justice System: The Changing Roles of the Armed Forces and the Police, Boston, MA: Northeastern University Press.

L'Heuillet, H. (2002), La généalogie de la police, Cultures et Conflits, no. 48, pp. 109-132.

Manning, P. (1991), Community policing as a drama of control, in: Green, J.R. \& Mastrofski, S.D. (eds) Community Policing: Rhetoric and Reality, Praeger, New York.

Monjardet, D. (1992), “Quelques conditions d'un professionnalisme discipliné”, Déviance et Société, Vol. 16, no. 4, pp. 399-403.

Monjardet, D. (1996), Ce que fait la police: sociologie de la force publique, Editions La Découverte, Paris.

Monkkonen, E.H. (1996), The urban police in the United States, in: Emsley, C. \& Knafla, L.A. (eds) Crime History and Histories of Crime: Studies in the Historiography of Crime and Criminal Justice in Modern Society, Greenwood Press, Westport, CT.

Monkkonen, E.H. (2002 [1997]), Policing in the United States, 1930-1972, in: Crime, Justice, History, Cleveland, $\mathrm{OH}$ : Ohio University Press.

Moynahan, G. (1937), "Motor vehicle registration in California", The California Highway Patrolman, Vol. 1, pp. 24ff.

Offerlé, M. (ed.) (1997), "Etatisations”, Genèses, Vol. 28, pp. 1-4.

Pérez-Diaz, C. (1998), Jeux avec les règles pénales, le cas des contraventions routières, L’Harmattan, Paris.

Rubin, H. (1989), "The CHP proudly celebrates six decades of serving California motorists (Part I)", California Highway Patrolman, Vol. 53, no. 10, 9-12.

Starr, K. (1985), Inventing the Dream: California through the Progressive Era, Oxford University Press, New York.

Suleiman, E. (1978), Elites in French Society, Princeton University Press, Princeton, NJ. 
284 F. Hamelin \& V. Spenlehauer

Teaford, J.C. (2002), The Rise of the States: Evolution of American State Government, Johns Hopkins University Press, Baltimore, MD.

Thoenig, J.C. (1994), "La gestion systémique de la sécurité publique", Revue française de sociologie, Vol. 35, no. 3, pp. 357-392.

Tilly, C. (1992), Coercion, Capital and European States, AD 990-1990, Blackwell, Oxford.

Vollmer, A. (1936), The Police and Modern Society, California Press, University of Berkeley, CA.

White, W.H. (1937), "California Highway Patrol Training School", The California Highway Patrolman, Vol. 1, pp. 30ff.

Wilson, C. (2000), Cop Knowledge, Police Power and Cultural Narrative in Twentieth-century America, University of Chicago Press, Chicago, IL/London.

Wilson, P.R. \& Chappell, D. (1971), "The effects of police withdrawal from traffic control: A comparative study", Journal of Criminal Law, Criminology and Police Science, Vol. 61, no. 4, pp. $567-572$. 